\title{
Cahn-Ingold-Prelog Priority System
}

National Cancer Institute

\section{Source}

National Cancer Institute. Cahn-Ingold-Prelog Priority System. NCI Thesaurus. Code C103219.

Rules created by Robert Sidney Cahn, Christopher Kelk Ingold and Vladimir Prelog to name stereoisomers in organic chemistry. 